\title{
MONETARY AND FISCAL MANAGEMENT, FINANCE, AND GROWTH
}

\author{
THORVALDUR GYLFASON
}

CESIFO WORKING PAPER NO. 1118

CATEgORy 5: Fiscal Policy, Macroeconomics and GrowTH JANUARY 2004

An electronic version of the paper may be downloaded

- from the SSRN website:

- from the CESifo website:

WWW.SSRN.com

www.CESifo.de 


\title{
MONETARY AND FISCAL MANAGEMENT, FINANCE, AND GROWTH
}

\begin{abstract}
This lecture addresses three related aspects of monetary and fiscal management in Europe and elsewhere. First, I discuss the implications of economic integration for monetary and fiscal policy, especially the narrow focus on low inflation as the main objective of monetary policy. I argue that because inflation springs from several sources, monetary authorities held responsible by law for maintaining low inflation need to exercise their newfound independence by reserving the right to address all sources of inflation. In this context, I also ponder the question whether increased independence of fiscal policy from short-term political interference would be desirable. Second, I present new empirical evidence of the relationship between inflation, finance, and economic growth across countries, arguing that long-run growth considerations provide an important additional justification for why price stability ought to remain a priority of independent policy makers. Third, I review some further aspects of the relationship between fiscal policy and economic growth, emphasizing the traditional three-pronged role of fiscal management: stabilization, allocation, and distribution, all of which can be conducive to growth. The argument leads to the conclusion that only the stabilization function of fiscal policy and perhaps also some aspects of the allocation function could be usefully delegated in an attempt to immunize them from shortsighted and socially counter-productive political interference, but not the distribution function.
\end{abstract}

JEL Classification: E50, E60, O11.

\author{
Thorvaldur Gylfason \\ University of Iceland \\ Faculty of Economics and Business \\ Administration \\ Oddi v/ Sturtugötu \\ 101 Reykyavik \\ Iceland \\ gylfason@hi.is
}

Thorvaldur Gylfason is Research Professor of Economics at the University of Iceland, Research Associate at SNS - Center for Business and Policy Studies, Stockholm, and Research Fellow at CEPR, London, and CESifo, Munich. This paper contains the transcript of my NÖG lecture delivered at the Annual Meeting of the Austrian Economic Association in Klagenfurt 16-17 May 2003. I am grateful for the hospitality of the Austrian Economic Association as well as for the comments received from my discussant, Eduard Hochreiter, and from other conference participants following the lecture. 


\section{Brief introduction}

The economic and monetary integration of Europe has transformed the political and institutional landscape of the continent in recent years. This transformation presents important new challenges for public authorities as well as for the European peoples at large. Old nation states are now in the process of sharing their sovereignty among themselves for their own benefit as well as for the benefit of the European community as a whole. To an unprecedented degree, they are also delegating authority within and across nations in an attempt to strengthen European democracy and improve economic performance. These changes call for new institutional architecture. Recent decades have seen important new judicial, political, and economic institutions emerge and evolve, most recently the European Central Bank (ECB). It seems unlikely that Europe has reached the end of this road. On the contrary, as further progress is made towards the common goal of European unity in the years ahead, new arrangements for economic and political cooperation will see the light of day.

In this lecture I intend to discuss mainly fiscal and monetary affairs, in three parts. First, I intend to discuss some implications of European economic integration for monetary and fiscal policy - in particular, I want to emphasize the important but not yet widely acknowledged implications of the narrow, almost exclusive focus on low inflation as the main objective of monetary policy in Europe. In second place, I want to consider the relationship among inflation, finance, and economic growth across countries by reviewing some recent cross-country empirical evidence of this relationship, and I then want to discuss the implications of this evidence for the optimal design of the framework of monetary and fiscal management in Europe, with emphasis on the long-run goals of economic stabilization. Third, to finish the argument, I intend to discuss a bit further the relationship between fiscal affairs and economic growth, including the long-run implications of allocation and distribution.

\section{Implications of economic integration}

Nowhere perhaps has the ongoing economic integration of Europe had such farreaching consequences thus far as in the field of monetary policy. Today, twelve out of fifteen member states have adopted the euro. As of the middle of the year 2004, at least 22 out of 25 member states will have done so, or have resolved to do so. In view of the successful launch of the euro, concerns about the potentially divisive 
consequences of a common currency among European nations speaking different languages seem to have subsided. Also, Europe now has a joint central bank that is committed, by law, to maintaining low inflation.

The new legal commitment to low inflation has fundamental implications for economic policy, of two kinds.

First, the new regime dictates a narrow focus on low inflation as the overriding objective of monetary policy, to the virtual exclusion of other policy objectives. This chief goal is to be accomplished through inflation targeting, an increasingly widespread method of monetary management also outside the Economic and Monetary Union (EMU), such as in the United Kingdom and Sweden, for example. But here we have to bear in mind that inflation can stem from many different sources and thus depends on various factors other than monetary policy undertakings. These other factors include, obviously, fiscal policy and practice, general economic efficiency, economic and political institutions, and so on. This is as expected: after all, there are considerable inflation differentials within Europe despite its common monetary policy. Not long ago, it is true, some influential economists viewed inflation as being always and everywhere a monetary phenomenon. Their numbers, though, have dwindled in the light of experience. Even Milton Friedman recently conceded to the Financial Times (7 June 2003): "The use of quantity of money as a target has not been a success ... I'm not sure I would as of today push it as hard as I once did."

What does this mean? It means that if the ECB and, by extension, national central banks are held responsible for maintaining low inflation, they may need to reserve the right to address all major sources of inflation rather than confine themselves to monetary aggregates, interest rates, and exchange rates as they did in the past. How would they do this? Mainly through attempts at friendly persuasion, a technique used with apparent success by the Federal Reserve Board (Fed) in the United States. The crux of the matter is this: insofar as inflation can be traced to fiscal imbalances, for example, central banks cannot fairly and logically be held responsible for containing inflation unless they are clearly authorized to address fiscal issues head on, including questions concerning the institutional framework of fiscal affairs. In other words, if they are to be held accountable for inflation, and if they are to succeed, central banks should reserve the right to suggest, for example, that the fiscal policy framework be put on a similar footing as monetary policy - that is, depoliticized as far as possible. 
This line of reasoning suggests a general principle. If some action by a third party - for example, the fiscal authorities or, say, labor market organizations - helps reduce inflation, then the Central Bank should support this action. This is why central banks would be right to plead for wage restraint and, perhaps more to the point, for reforms of labor market arrangements for the sake of creating market-friendly conditions for wage restraint - that is, for wage settlements that do not systematically outpace the rate of growth of productivity, a common consequence of nationwide central bargaining on wages and salaries in some European countries over the years. And this is also why central banks would be justified in arguing for more competition in the market for goods and services, for instance, as well as for fiscal prudence.

The mechanism I have in mind here is quite simple. Greater efficiency in resource allocation imparts a boost to the supply side of the economy, thereby putting downward pressure on prices, as if aggregate demand had been curtailed. Moreover, supply stimulus does not have the same disadvantageous side effects on economic activity as does demand restraint. By the same logic, central banks would also be right to criticize, and to suggest ways to relieve, for example, the huge inefficiency created by the Common Agricultural Policy (CAP) of the European Union (EU). To repeat, once more: increased efficiency stimulates the supply side, thereby helping contain inflation, at least for a while. Inflation is not always and exclusively a monetary phenomenon. After all, inflation is a relative price, as Fischer (1993) has emphasized, among others. Because inflation is, or reflects, a relative price - that between nominal and real assets - inflation can have real causes and real effects, as empirical evidence suggests it does (for a survey, see Temple, 1999).

As a rule, therefore, central banks would be right to support growth-friendly reforms because growth helps restrain inflation. Indeed, in the new institutional environment where central banks are held accountable for keeping inflation low, they can be said to have a duty to attack inflation on all fronts, with the means at their disposal. This is why Fed Chairman Alan Greenspan is not straying outside the legitimate range of monetary policy when he advocates education reform, as he has done on occasion. No, he understands that education is good for growth and hence helps keep inflation under control, so he has every reason to encourage politicians to look ahead and pay attention to education. The argument I am making is this: central bankers need to take a broad view of their responsibilities now that they are required by law to keep inflation at bay. 
True, some might object that a central bank involving itself in, for example, the macroeconomic consequences of agricultural policy could be accused of political interference. To my mind, that would, in the new legal environment, be an unfair and unhelpful accusation. In recent years, central banks in Europe and elsewhere have been granted greater statutory independence from political authority precisely in order to give them greater freedom to pursue the objectives assigned to them by law. Naturally, their newfound independence is confined to means rather than ends: democratically elected politicians set the targets of economic policy as before, but politically appointed central bankers are now free to choose the instruments by which these targets - say, two percent inflation per year - are to be pursued. ${ }^{1}$ The independence now vested in central banks is a natural extension of a long-standing depolitization process that has covered a broad spectrum of social affairs. There can be no controversy about the need for independent, yet accountable, public institutions such as courts of law. The same applies to universities and news media, whether they are publicly or privately owned. What has been happening over the past few years is that central banks have, for good reason, been added to a lengthening list of social institutions in need of depolitization.

This brings me to the second implication of the legal commitment to low inflation. If the law prescribes low inflation, and if political interference in fiscal policy through vote buying before elections, irresponsible tax cuts and such is a significant source of fiscal imbalances and inflation, then is fiscal policy not also a possible candidate for depolitization? - like monetary policy. If not, then why not?

To sharpen the focus of the argument, let me begin with an example from Iceland, involving fisheries management. I want to do this because fisheries management in Iceland is, or ought to be, intimately linked to fiscal policy. This is so because, in long-run equilibrium, the natural resource rent from the fisheries has been estimated to amount to some 5 percent of Iceland's gross domestic product (GDP). This makes Iceland unique among industrial countries, and clearly makes fisheries policy a macroeconomic as well as fiscal concern. For comparison, public expenditure on education at all levels in Iceland amounted to less than 6 percent of GDP in the year 2000. Under the present fisheries policy management system, which, by law, defines the fish resources in Icelandic waters as common property of the Icelandic nation, just

\footnotetext{
${ }^{1}$ For a review of the main issues involved and some empirical evidence, see Cukierman (1992).
} 
as the oil wealth within Norway's jurisdiction is defined as a common property resource, Icelandic boat owners are allocated transferable catch quotas, free of charge, based on their catch experience in 1981-1983 because the current regime was launched in 1984. These quotas are quite valuable, as can be deduced from the high prices at which they are freely, and legally, traded among boat owners as well as from the macroeconomic magnitude of the long-run resource rent involved. By thus implicitly subsidizing the fisheries by not charging the boat owners a fair price - that is, market price - for the quotas through landing fees or by auctioning them off, the government thus foregoes substantial revenue, which could be used either to finance necessary social expenditures on education and health care or to reduce taxes, or both. The present scheme is doubly inefficient: first, the implicit subsidy delays necessary reform and rationalization in the fishing industry because the fisheries management regime, like farm policy, is essentially an instrument of the government's regional policy, and second, the failure to reorganize public finances by replacing inefficient taxes to some extent by fishing fees imposes unnecessary deadweight losses on the economy because fishing fees, like natural resource fees in general, are a more efficient source of public revenue than distortionary levies such as the income tax, the value-added tax (VAT), and import duties.

The main objection that has been raised to the above arguments in public debate in Iceland is that politicians would squander the revenue from fishing fees and hence cannot be entrusted with the money. Better then to leave the money in private hands, that is, with the boat owners, or so the argument goes. The boat owners at the receiving end aside, what are we to make of this counterargument? - that new revenues from fishing fees need to be kept out of the hands of politicians. After all, as has been discussed above, monetary policy is now widely considered to be too important to be left to insufficiently far-sighted politicians, and this is why, in recent years, central banks in many countries have been granted greater independence from political authority. Therefore, the question now arises as to whether this argument cannot be extended to at least the stabilization function of fiscal policy, as suggested by the specific example from Icelandic fisheries policy, and to some extent, perhaps, to the allocation function of fiscal policy as well - more on this later.

This approach has led me to conclude that the determination of fishing fees in Iceland and the allocation of revenues from the fees could, if necessary, be decoupled from the political process by setting up an independent Open Market Fisheries 
Committee based on the precedent set in modern central banking legislation (for a detailed description of the proposal, see Gylfason and Weitzman, 2003). The advantage of this approach is that urgent fiscal and structural reforms can thus be assured, unimpeded by political interference. The next question, therefore, is this: Should this principle perhaps be applied more widely in the fiscal policy sphere? Should fiscal policy be made more independent from political interference?

Unlike monetary policy, fiscal policy clearly belongs at the national level. Even so, the EU membership has agreed to certain common rules involving various numerical - and, yes, arbitrary - targets in the Maastricht Treaty as well as in the Stability and Growth Pact. These numerical targets call for a certain degree of fiscal harmonization, even if the formulation and execution of fiscal policies remains firmly entrenched in the hands of national governments. Recent difficulties with meeting the agreed targets in some European countries - notably, Germany and France - and the resulting, presumably temporary, suspension of the Stability and Growth Pact in late 2003 raise the question as to whether there is a further need for common standards for fiscal institutions, including, perhaps, common laws governing some aspects of the fiscal policy framework, such as the path of public debt, the fiscal position at full employment, and the fiscal relations of local and national governments. Specifically, the question is this: can budget discipline and fiscal efficiency be improved through delegation? - that is, depolitization.

Several proposals in this vein have been presented in recent years. For example, Professor Alan Blinder, former vice-chairman of the Fed, has proposed the formation of a Fiscal Policy Committee in the United States and elsewhere vested with the authority to determine the structure of taxes, but not the level or composition of government spending (Blinder, 1997, 1998). The underlying idea is that public policies that require substantial technical expertise and long time horizons - like modern monetary policy - are particularly well suited to depolitization. The need for short decision lags as well as for freedom from special interest groups trying to sway public policy in their own favor further strengthens the case for more independent fiscal policy. At issue here is the perceived need to separate fiscal stabilization from allocation and distribution - i.e., depoliticize the stabilization function of fiscal policy, leaving the other two functions intact. The basic idea here is this. Elected politicians (e.g., national parliaments) set the path - i.e., medium-term targets - of government expenditures and taxes, based on allocation and distribution objectives. Clearly, some 
nations prefer to channel a large proportion of their economic activity through their central or local governments, while others have a preference for a small private sector. The organization of education and health care in the United States and Europe is a case in point: in America, the private sector plays a considerably larger role in the provision of education and health care than in Europe. Given politically established targets, the Fiscal Policy Committee would be authorized to allow short-run variations around the medium-term path by, for example, setting individual tax rates (such as the VAT) or individual expenditure items (such as grants to regions) in accordance with the perceived need to stabilize the economy by fiscal means. ${ }^{2}$ To take another example, the Business Council of Australia presented a few years ago a detailed proposal in the same vein, mindful of the constitutional restraints in Australia on legislation governing the distribution of the responsibility for fiscal affairs.

Suppose we accept the argument that, in order to ensure efficiency and hence economic growth in the long run, fiscal as well as monetary stabilization needs to be depoliticized. If so, why not depoliticize some of the allocation function of fiscal policy on similar efficiency grounds as well? - including, for instance, agricultural policy. As mentioned before, one of the rationales for delegating the stabilization function of fiscal policy is to restrict the access of special interest groups to the corridors of political power, an argument that applies with special force to farm protection which at present costs consumers and taxpayers in OECD countries nearly EUR 1 billion every day. The inefficiency of the CAP and its counterparts in the United States and Japan can hardly be overstated. Every year, the costs imposed by protectionist farm policies on consumers and taxpayers in the OECD region exceed Switzerland's gross national product (GNP). Furthermore, the protection thus extended to farmers in the industrial countries has wrought havoc on many developing countries by denying their farm products access to world markets. Also, it has complicated the accession of the East and Central European countries to the EU by making it necessary for financial reasons to disqualify farmers in Poland and other accession countries from receiving as much support through the CAP as farmers residing in the older member countries are entitled to, and thus virtually to breach the fundamental principle, laid down in the Treaty of Rome, that forbids or at least disavows any kind of discrimination by nationality. Equal treatment as prescribed by

\footnotetext{
${ }^{2}$ For a further discussion and description of such proposals, see Corsetti et al. (2003, Chapter 3).
} 
the Treaty of Rome would have bankrupted the CAP. This state of affairs could have been avoided by a timely, and long overdue, reform of the CAP (Gylfason, 1995).

Another example can be taken from the field of pensions. Here we have a policy challenge that politicians in Europe and elsewhere have not yet managed to tackle very successfully. Yet, the stability of demographic developments makes it easier in this case than in many others to foresee a pending danger that consists in the gradual but certain change of the age composition of the European population: that is, too few people of working age a generation from now to pay for present pensions obligations to old people whose numbers will swell (Lindbeck and Persson, 2003). This policy challenge shares several attributes of monetary and fiscal stabilization and partly also allocation, including the somewhat technical and long-run nature of the problem and the resulting temptation of shortsighted politicians to postpone action. This example helps explain why extended mandate periods for elected officials will not solve all the problems that well-designed delegation is intended to solve. The optimal mandate period in a democracy is bound to be shorter than might be required to focus political attention and to secure legislative action on inherently long-run issues such as pensions. For these reasons, pension reform may be a good candidate for delegation.

But clearly, this argument cannot be taken too far. Even if some of us may be willing to consider delegating government authority in agricultural policy to an independent group of people that is less impressed than many politicians by the urgency of preserving the status quo in this area, most of us would balk at the notion of leaving the allocation of national resources between, say, the private sector and the public sector to a Fiscal Policy Committee. There are aspects of the allocation function of stabilization policy that are inherently political and we do not want to completely depoliticize politics, do we? Like it or not, politics is necessary. Here, the challenge of economists is to suggest ways to try to restrain politicians to maximize their usefulness without stifling the political process. And, it goes without saying, the distribution function of fiscal policy cannot be delegated.

\section{Inflation, finance, and economic growth}

To recapitulate, the main argument for disconnecting fiscal as well as monetary stabilization from politics concerns the economic consequences of price stability in the long run. Inflation is perceived to impede economic growth over time. Because it 
takes time for the consequences of high inflation and slow growth to materialize with full force, myopic politicians may be tempted to use stabilization policy to inflate the economy for short-term political gain and disregard the implications of their actions for the future.

The idea that inflation hurts economic growth in the long run is remarkably recent. It is about as old as the idea of independent central banks, and this is probably not a coincidence. For a long time, it was widely believed that economic growth was exogenous - that is, that growth was impervious to economic forces, including macroeconomic management. The main emphasis of monetary and fiscal policy was on the maintenance of high employment and low inflation, but long-run growth was widely regarded as being outside the range of economic policies except possibly in the field of education and manpower management (Nelson and Phelps, 1966). Development economics was different from growth theory, true: economic development was considered endogenous all along, from Adam Smith to Arthur Lewis, but development economics had landed outside the mainstream of economic analysis. In the neoclassical growth model, long-run growth was still exogenous.

This state of affairs continued until the theory of economic growth underwent a radical transformation in the mid-1980s. It then became clear that it could be useful to view economic growth as endogenous, in the sense that it was capable of responding to economic well as technological forces over long periods. At the same time, new international data on economic growth and some of its main potential determinants became widely available, triggering an avalanche of empirical cross-country studies of economic growth and development. Out of this environment grew the idea that perhaps high inflation might hurt economic growth in the long run.

But even among those who came around to viewing long-run growth as endogenous, there was continued skepticism about the effects of inflation on growth, not only as an empirical matter but also in theory. The initial disbelief stemmed from the view that inflation is a monetary phenomenon and growth is real, so inflation could not possibly be relevant for growth (Sala-i-Martin, 1991). But inflation is a relative price, as Fischer (1993) emphasized, among others, and thus capable of influencing real variables, including growth. Recent econometric evidence suggests that inflation above 40 percent per year (Bruno and Easterly, 1998), or even ten to fifteen percent per year (Gylfason and Herbertsson, 2001), goes along with less rapid long-run economic growth across countries. Khan and Senhadji (2001) propose an 
even lower threshold beyond which inflation begins to hurt growth, or one to three percent a year for industrial countries and eleven to twelve percent for developing countries.

If this is the evidence, what is the theory? The recent literature has suggested several channels through which inflation is capable of impeding economic growth over long periods. It can do so by

(a) Reducing real interest rates and weakening incentives to save;

(b) Distorting relative prices and production;

(c) Creating uncertainty, and havoc;

(d) Jacking up real exchange rates, thus hampering exports;

(e) Scaring foreign investors away.

Here, however, I want to emphasize yet another channel through which high inflation may hurt growth: namely, by punishing households and firms for holding money, thus reducing liquidity and thereby depriving the economic system of the lubrication that is necessary for it to function smoothly - that is, for achieving full economic efficiency and rapid growth. What is the evidence for this?

Figure 1 shows the relationship between per capita economic growth and liquidity as measured by the ratio of money and quasi-money and GDP from 1965 to 1998 in 87 countries, some rich and some poor. The figure shows that an increase in money and quasi-money relative to GDP by 20 percentage points from one country to another is associated with an increase in annual per capita growth by one percentage point. The Spearman rank correlation is 0.66 and significant. The Spearman correlation is less sensitive to outlying observations than the standard Pearson correlation. Clearly, what we see in Figure 1 is a mere correlation: the causation can run both ways. Slow growth may hinder financial development just as financial maturity may spur growth. Even so, the policy implication is evident: keeping inflation low and liquidity reasonably high is most likely to be good for growth. This brings us to Figure 2 which shows the cross-sectional relationship between liquidity and inflation - specifically, the inflation distortion or the implicit rate of inflation tax, measured by the rate of inflation divided by one plus the rate of inflation - in the same 87 countries over the same 33-year period as before. This nonlinear transformation of the inflation rate is intended to reflect the phenomenon that a given decrease in inflation has a stronger proportional effect on liquidity at low rates of inflation than at high rates. In Figure 2 
we can see a clear inverse association between liquidity and inflation. The Spearman rank correlation is -0.45 and significant.

Figure 1. Financial depth and economic growth

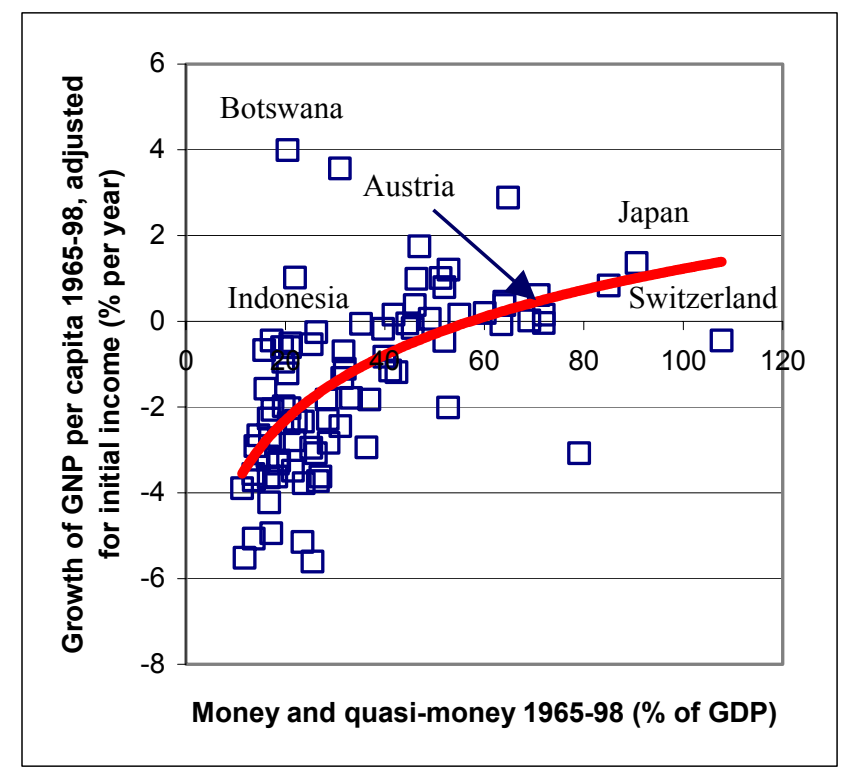

Figure 2. Inflation and financial depth

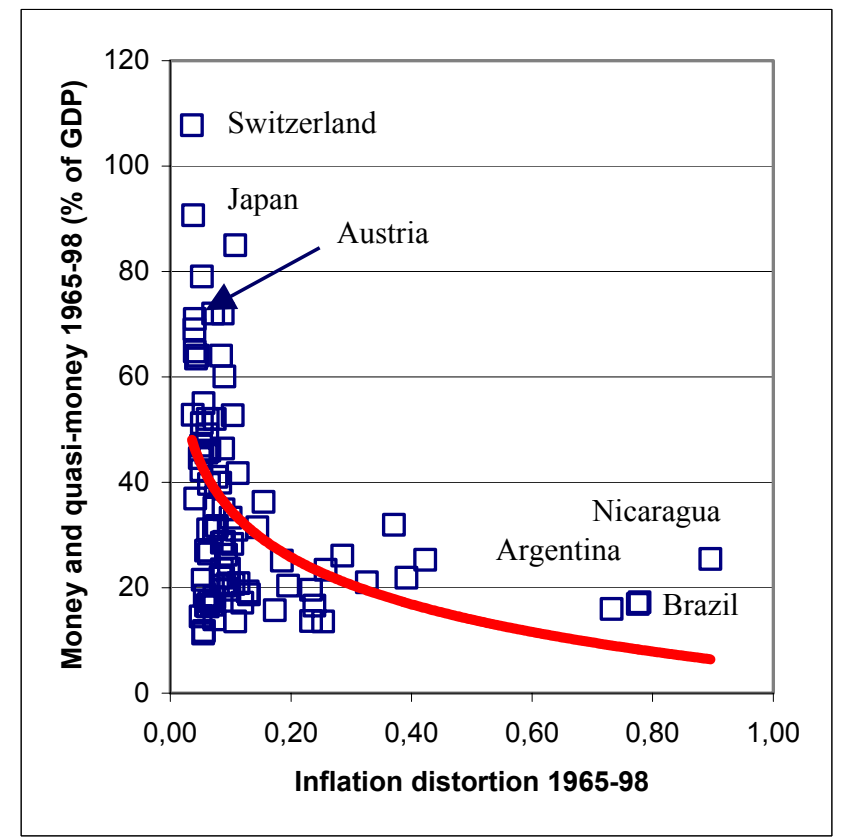

Adding Figures 1 and 2 conveys a clear impression of an inverse cross-country relationship between inflation and economic growth, via financial depth or maturity. 
There is, however, no clear evidence of a two-dimensional correlation between inflation and growth around the world. The reason is that the relationship between inflation and growth is a complicated one, and involves several factors other than financial maturity, as mentioned before - among them, real interest rates and saving, real exchange rates and trade, and probably also political governance and stability. In short, the relationship between inflation and growth is too complicated to be discernible to the naked eye as a two-dimensional cross-country correlation summarizing the impressions conveyed by Figures 1 and 2. Even so, the relationship exists as can be ascertained by multiple regression analysis.

The next step, therefore, is to estimate a series of growth regressions for the same 87 countries as before, again during 1965-1998. The data are taken from World Bank's World Development Indicators (2002), except the data on natural capital that are taken from World Bank (1997). The strategy here is to regress the rate of growth of national economic output per capita on the inflation distortion, defined as in Figure 2 , and then to add other potential determinants of growth to the regression in order to observe the robustness of the initial result - that is, to see whether the inflation variable survives the introduction of additional explanatory variables that are more commonly used in empirical growth research.

Table 1 presents the results of this exercise. Model 1 shows that there is, in fact, a statistically significant bivariate relationship between inflation and growth in the data even if it is invisible to the naked eye. When natural resource dependence, measured by the share of natural capital in total capital, which comprises physical, human and natural capital (but not social capital; see World Bank, 1997), is added to the regression in Model 2 in accordance with the resource curse hypothesis (Sachs and Warner, 1995), we see that natural resource dependence hurts growth as hypothesized without knocking out the negative coefficient on inflation. In Model 3, the logarithm of initial income (i.e., in 1965) is added to capture conditional convergence - the idea that rich countries grow less rapidly than poor ones because the rich have already exploited more of the growth opportunities available to them, by sending more young people to school, for instance. Initial income is defined as purchasing-power-parity adjusted GNP per capita in 1998 divided by an appropriate growth factor to ensure consistency between our income measures in 1965 and 1998 and our measures of economic growth between those years. Here we see that the coefficient on initial income is significantly negative as expected; the other two coefficients survive. Then, 
in Model 4, we add the share of gross domestic investment in GDP and find that it makes a contribution to growth as expected, even if no attempt has been made to adjust the figures for the quality of investment, a desirable adjustment to make in principle, but difficult in practice. In Model 5, we then proceed to add education, represented by the logarithm of the secondary-school enrolment rate, the measure of education most commonly used in empirical growth research; the logarithmic formulation reflects diminishing returns to education. Again, education stimulates growth without displacing any of the variables inherited from the preceding models. At last, in Model 6, we enter population growth into the regression to see if it matters for growth as suggested by the Solow model. The answer is Yes: increased population growth hurts economic growth as expected, without reducing the statistical significance of the explanatory variables already included. Specifically, it takes an increase in annual population growth of less than two percentage points to reduce per capita growth by one percentage point. The bottom line of Table 1 shows how the adjusted $\mathrm{R}^{2}$ rises gradually as more independent variables are added to the growth regression and ultimately reaches 0.64 , indicating that Model 6 explains almost two thirds of the cross-country variations in the growth of output per capita.

The results from Model 6 accord reasonably well with a number of recent empirical growth studies, except relatively few researchers have yet managed to nail down the cross-country relationship between inflation and growth. In Model 6, the coefficient on the natural resource variable suggests that an increase in the share of natural capital in national wealth by 25 percentage points reduces per capita growth by one percentage point. Beginning with Sachs and Warner (1995), several recent studies have reported a similar conclusion, based on different measures of natural resource dependence. The coefficient on initial income suggests a convergence speed of 1.3 percent per year, which is not too far below the two to three percent range typically reported in econometric growth research. The coefficient on the investment rate suggests that an increase in investment by ten percent of GDP increases annual per capita growth by one percentage point, a typical result in those growth studies that report a statistically significant effect of investment on growth. The coefficient on the education variable in Model 6 means that an increase in secondary-school enrolment by a third of each cohort (e.g., from 33 percent to 66 percent) increases per capita growth by one percentage point. 
Table 1. Regression results on economic growth

\begin{tabular}{|c|c|c|c|c|c|c|}
\hline & Model 1 & Model 2 & Model 3 & Model 4 & Model 5 & Model 6 \\
\hline $\begin{array}{l}\text { Inflation } \\
\text { distortion }\end{array}$ & $\begin{array}{l}-2.52 \\
(2.07)\end{array}$ & $\begin{array}{l}-2.46 \\
(2.37)\end{array}$ & $\begin{array}{l}-2.26 \\
(2.25)\end{array}$ & $\begin{array}{l}-1.95 \\
(2.25)\end{array}$ & $\begin{array}{l}-1.97 \\
(2.49)\end{array}$ & $\begin{array}{l}-1.61 \\
(2.14)\end{array}$ \\
\hline Natural capital & & $\begin{array}{l}-0.09 \\
(5.75)\end{array}$ & $\begin{array}{l}-0.10 \\
(6.52)\end{array}$ & $\begin{array}{l}-0.07 \\
(5.01)\end{array}$ & $\begin{array}{l}-0.04 \\
(2.93)\end{array}$ & $\begin{array}{l}-0.04 \\
(2.49)\end{array}$ \\
\hline Initial income & & & $\begin{array}{l}-0.45 \\
(2.67)\end{array}$ & $\begin{array}{l}-0.45 \\
(3.05)\end{array}$ & $\begin{array}{l}-1.10 \\
(5.39)\end{array}$ & $\begin{array}{l}-1.27 \\
(6.42)\end{array}$ \\
\hline Investment & & & & $\begin{array}{c}0.15 \\
(5.41) \\
\end{array}$ & $\begin{array}{c}0.09 \\
(3.36) \\
\end{array}$ & $\begin{array}{c}0.10 \\
(3.74)\end{array}$ \\
\hline $\begin{array}{l}\text { Secondary } \\
\text { education }\end{array}$ & & & & & $\begin{array}{c}1.24 \\
(4.24)\end{array}$ & $\begin{array}{c}1.07 \\
(3.82)\end{array}$ \\
\hline $\begin{array}{l}\text { Population } \\
\text { growth }\end{array}$ & & & & & & $\begin{array}{l}-0.56 \\
(3.42)\end{array}$ \\
\hline Adjusted $\mathrm{R}^{2}$ & 0.04 & 0.30 & 0.35 & 0.51 & 0.60 & 0.64 \\
\hline
\end{tabular}

Note: t-values are shown within parentheses. Estimation method: Ordinary least squares. Number of countries: 87 . No outliers were excluded.

Last but not least, the coefficient on inflation in the northeast corner of Table 1 means that an increase in inflation from zero to ten percent per year reduces per capita growth by 0.15 percentage points per year. This means that bringing inflation down from 50 percent a year to five percent would increase per capita growth by almost half a percentage point, other things being the same. This result is within the range of empirical results reviewed by Gylfason and Herbertsson (2001, Table 1). Is this a little or a lot? The average rate of growth of output per capita was 1.3 percent on average in the sample as a whole. This suggests that the effects of inflation on economic growth shown in Table 1 are economically as well as statistically significant.

In conclusion, empirical evidence seems to support the view that high inflation is harmful to economic growth across countries. This lends extra force to the modern emphasis on price stability as the overriding objective of monetary policy and on independent, yet democratically accountable, central banks as the most effective method of achieving this objective. Hence, if it is the need to immunize the stabilizing function of monetary policy from political interference for long-term gain that has produced independent central banks, then a similar argument can be applied to the stabilizing role of fiscal policy. This is my main point. But if the stabilization function 
of fiscal policy needs to be disconnected from politics because inflation is bad for long-run growth, how about the allocation and distribution functions? Now the plot thickens.

\section{Fiscal policy and economic growth}

Let us now move from stabilization to allocation and distribution.

The exercise of the allocation role of the government has important consequences for long-run growth. In Section II, the inefficiency of agricultural policies in the OECD countries (with the exception of New Zealand, since 1984) was taken as a case in point. In the industrial countries, excessive government interference in the operation of agricultural commodity markets and trade has distorted incentives, thus thwarting social efficiency on a grand scale at home and abroad. Let me now take another example. Around the world, the government has an important role to play in the provision of education, health care, and infrastructure, even if the scope and methods of government interference in these areas vary from country to country. This is the main reason why it is generally impossible to say whether big government is bad or good for growth: the answer depends on how the government spends its tax revenues. High taxes that are judiciously used to improve education, health care, and infrastructure are probably good for growth.

Take education. There are good grounds for government involvement in education around the world. This has to do with externalities: because the social benefits of education exceed private benefits, free markets on their own would fail to provide sufficient education. But market failure does not guarantee government success. The complaints of parents and pupils about the quality of education offered by many public schools are legendary, and not only in our part of the world. In developing countries, many poor parents prefer to remove their children from public schools that cost them nothing in the sense that the schools are funded out of general tax revenues, and place them instead in private schools that charge tuition and provide better education. In some industrial countries, there is likewise a widespread feeling that the government has not taken its role in education seriously enough. The problem is particularly pronounced in higher education in some European countries where the government has been unable or unwilling to provide sufficient funding to meet increased popular demand for higher education and, at the same time, unwilling to 
allow public universities to exploit market mechanisms to supplement their resources - through tuition fees, for example - and to manage their limited funds more efficiently. The problem of tertiary education is less severe in the United States where private colleges and universities are more common than in Europe. It is, therefore, not surprising that Europe lags behind the United States in college and university enrolments. In Austria, for instance, 58 percent of the relevant age group attended university in the year 2000, compared with 73 percent in the United States. ${ }^{3}$ This looks likes a classic case of a price ceiling (e.g., too low tuition fees on average) restricting the amount of the commodity in question - in this case, education. Hence, the problem of higher education in Europe has important features in common with the problems of agriculture discussed in Section II: excessive government interference in the functioning of free markets tends to impede social efficiency and therewith also economic growth over time.

Figure 3. Secondary education and economic growth

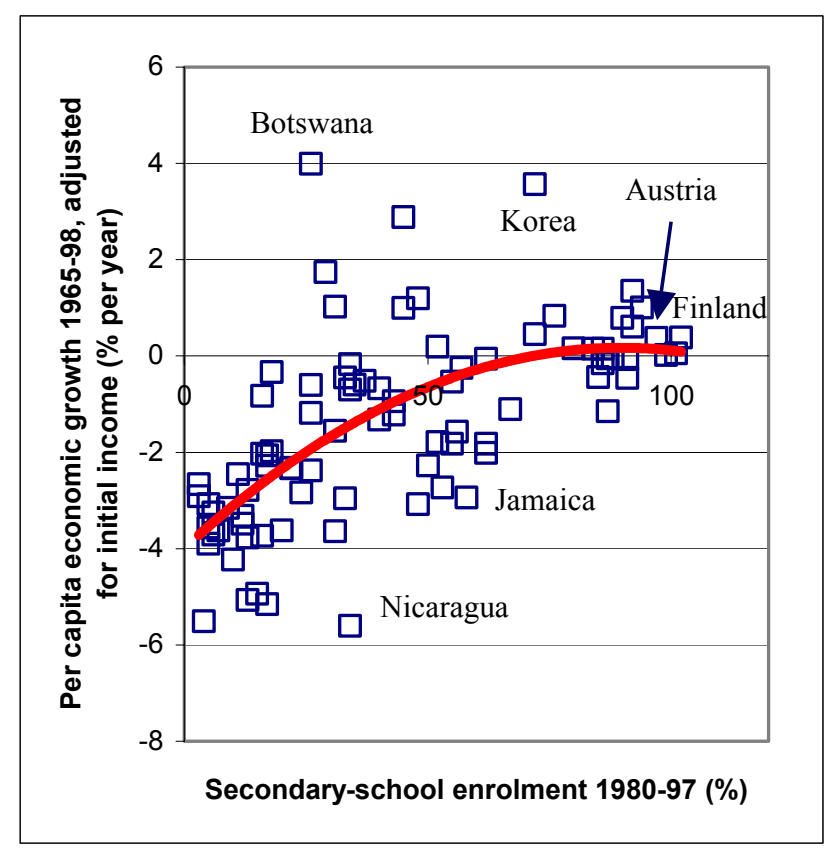

Empirical evidence suggests that increased education is associated with more rapid growth across countries. Figure 3 covers the same 87 countries as before (for comparison, see Table 1). The regression line drawn through the scatter plot indicates

\footnotetext{
${ }^{3}$ These figures are taken from the World Bank's World Development Indicators (2002). The original source is the United Nations Educational, Scientific, and Cultural Organization (UNESCO).
} 
that an increase in the secondary-school enrolment rate by 25-30 percentage points from one country to another goes along with an increase in per capita growth by one percentage point. The correlation is statistically as well as economically significant: the Spearman rank correlation is 0.72 . The curve shown fits the data a bit better than a straight line because of diminishing returns to education: increased education makes the greatest difference for growth when the standard of education is low to start with. As always, it would be desirable to distinguish quantity from quality, but this is difficult to do because the available and commonly used measures of education years of schooling and expenditure on education as well as school enrolment - reflect education inputs rather than outputs - quantity, that is, rather than quality.

What can we conclude from this discussion? Myopic governments tend to devote too few resources to education because they are not sufficiently concerned about the long-run effects of education on economic growth. In Europe, for instance, university education tends to be undernourished compared with America where the government has delegated a larger portion of the responsibility for higher education to the private sector. Does this mean, then, that education, like price stability, is too important to be left to politicians? The structure of the argument presented here seems to suggest that this may be the case. If so, perhaps partial delegation of authority in the field of education would better safeguard the long-run interests of the people. Perhaps it would be a good idea to have an Open Market Education Committee drawn up, like the Open Market Fisheries Committee mentioned in Section II, along the lines of modern central banking legislation. The basic principles are the same in the three cases - money, fish, and education. The challenge of holding the Open Market Committees democratically accountable while at the same time granting them the means to exercise their independence from political authorities without restraint is comparable in all three cases. It's an old story: tying one's hands can be a good thing.

How about health care? Do we here have another example of an allocation function of fiscal policy that could be delegated to an independent, yet accountable body? - an Open Market Health Committee. The problems encountered in health care provision are to some extent similar to those confronting education, but they are also more difficult to deal with in many ways, partly because of the asymmetric information available to health care providers and patients and because of legitimate concerns about equal or at least reasonably fair access to health care. A comparison between Europe and the United States shows a significantly different division of responsibility 
between the public sector and the private sector on the two continents. In Europe, public expenditure typically accounts for about a third or fourth of total expenditure on health care (the Austrian figure was 30 percent in the year 2000) compared with about a half in the United States where total expenditure on health care, public and private, exceeds the EMU average by almost a half (13 percent of GDP in the United States versus 9 percent in Europe). In the United States, in other words, the responsibility for health care has, in effect, been delegated to the private sector to a considerably larger extent than in Europe. Privatization aimed at a more productive division of responsibilities between the government and the private sector is an important aspect of the delegation of government authority.

In this context an example from Iceland may be instructive. General health care in Iceland is the almost exclusive responsibility of the central government while dental care is provided by the private sector. General health care is essentially free of charge in the sense that it is funded out of general tax revenues whereas dental care is provided at competitive market prices, except the dental care costs incurred by young people up to the age of eighteen and by pensioners and welfare recipients are subsidized by 50 percent by the government. The state of dental health in Iceland is excellent by world standards as is public health in general, as evidenced by the fifth highest life expectancy in the world (after Japan, Hong Kong, Sweden, and the Switzerland). The point of this comparison is that the centrally planned general health care sector in Iceland is an almost perpetual state of financial and organizational crisis, unable to cope with the demands placed on it by the public as evidenced by long waiting lists and overcrowded hospitals. Meanwhile, the dental care industry faces no comparable problems, no shortage of funds, and no waiting lists. An obvious inference to draw from this is that perhaps the publicly owned and operated health care sector may have something to learn from the private dental care industry.

A similar story can be told about infrastructure. The world is full of white elephants - public infrastructure projects whose social value does not justify their cost to taxpayers. This experience has resulted in the proliferation of privately funded infrastructure around the world - for example, roads, tunnels, and bridges financed by fees and tolls. The aim is a better balance in the division of labor between the public sector and the private sector and therewith more and better infrastructure. Here we have another instance where delegation can be achieved in part through privatization. 
To recapitulate, I have argued that some part of the allocation function of fiscal policy could, in principle, be delegated - that is, depoliticized - on the same grounds as monetary policy has been, or is in the process of being, delegated to independent central banks in an increasing number of countries. Such delegation may in some cases require new institutional arrangements - for example, Open Market Committees. The challenge of combining independence from political interference with democratic accountability is essentially the same as in the case of independent central banks and judiciaries. In other cases, a simple realignment of the division of responsibility between the government and private enterprise may be enough.

This brings me to the last point I want to make. I have argued that the case for delegation rests on the tendency of political authorities to downplay or underrate the long-run consequences of their actions and thus to neglect not only the long-run benefits of stable prices but also the long-run gains from the conservation of common property resources and the environment, the efficient functioning of agricultural commodity markets, pension reform, education, health care, and infrastructure - the list could be extended. But this does not mean that the government should be written out of the script and its authority diluted whenever a reasonable case can be made that the long-run effects of government policy are being neglected.

To see this, consider at last the distribution function of fiscal policy. The personal distribution of incomes and wealth and the various ways in which public policy could or should be used to redistribute incomes and wealth is an inherently political matter, more so, it would seem, than the allocation of resources among alternative uses and the stabilization of economic activity and prices even if both allocation and stabilization have significant distributional consequences. Therefore, the distribution function of government cannot possibly be depoliticized, no part of it; this goes without saying. Even so, recent empirical evidence suggests that distribution matters for long-run growth. What do the data say?

Figure 4 shows the cross-sectional relationship between per capita economic growth from 1965 to 1998 measured in the same way as in Figures 1 and 3 and the inequality of income or consumption as measured by the Gini index for 75 countries; the index is not available for twelve of the countries represented in Figures 1-3. The Gini index spans the range from about 25 in those countries, such as Austria and the Scandinavian countries, where the distribution of income is most egalitarian, to 60 or more in countries such as Brazil, Nigeria, and South Africa where the distribution of 
income is least egalitarian. The regression line through the scatter plot suggests that an increase of about twelve points on the Gini scale from one country to another goes along with a decrease in per capita growth by one percentage point per year on average. The Spearman rank correlation is -0.50 and significant.

Figure 4. Inequality and economic growth

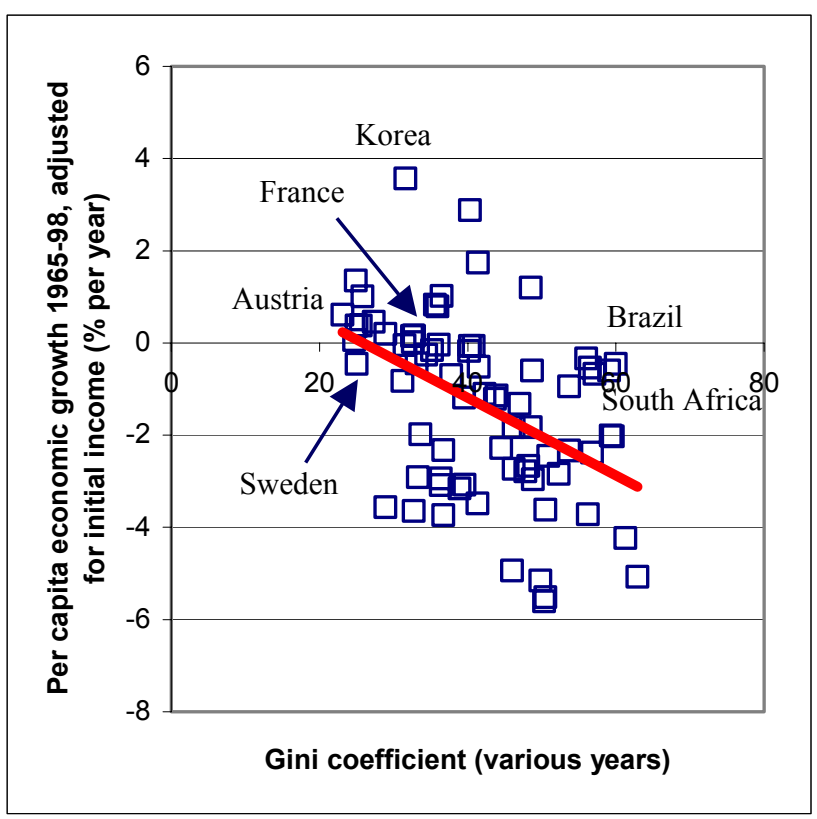

Interestingly, Figure 4 does not show any signs that the most egalitarian countries, like Austria, may have gone too far in the direction of increased equality and that less ambitious redistribution schemes through taxes and transfers would help them grow more rapidly. If that were the case, the best fit through the scatter plot would be a hump-shaped curve rather than a straight line. True, there are indications that the Scandinavian countries may perhaps have gone too far in the direction of increased equality through redistribution, thereby blunting incentives to work, save, and invest in education, but Figure 4 is not one of those indications.

There are several possible explanations for the cross-country pattern observed in Figure 4. Increased education may reduce society's tolerance of great disparities of income and wealth and thus spur economic growth as well as social equality and cohesion, which in turn is good for growth. Excessive inequality may trigger demands for redistribution that can hinder growth, but it may also trigger demands for more and better education that increases growth. Inequality is likely to strengthen education in poor countries where it is mostly the rich who can afford to go to school: in this case, 
more inequality then means a larger number of rich people and more schooling. On the other hand, inequality is likely to weaken education in rich countries where all but some of the poor can afford to go to school: more inequality there means a larger number of poor people and less schooling. Inequality may also lead to social conflict, political instability, and macroeconomic volatility all of which can hamper growth.

\section{In conclusion}

In this lecture, I have discussed some of the possible lessons that can be drawn from recent debates and legislation on monetary policy matters and central banking. Briefly stated, the argument I have made is the following. If monetary stabilization needs to be made immune from shortsighted political interference in consideration of the potential long-run growth gains from stable prices, then a similar case can be made, in principle, for a corresponding immunization of the stabilization function of fiscal policy. This, however, is not an easy thing to accomplish in countries where fiscal arrangements and institutions, unlike monetary ones, are circumscribed by constitutional clauses as well as by law. I then went on to suggest that perhaps a similar case could be made for taking certain aspects of the allocation function of fiscal policy out of the hands of politicians in cases where myopic political concerns have proved unresponsive or harmful to the long-run public interest. Agricultural policy, pension reform, education, health care, and infrastructure provision were suggested as possible candidates for some sort of delegation. Here, however, we are on thinner ice than in the case of monetary and fiscal stabilization because of the significant overlaps between the allocation function of fiscal policy and its distribution function. In particular, the distributional implications of education and, especially, health care would seriously complicate delegation of these important allocation roles of fiscal policy. After all, the distribution function of fiscal policy clearly belongs in the political arena, even if distribution probably matters for longrun growth, as recent empirical evidence seems to suggest. But even so, some degree of depolitization of the present functions of government beyond mere monetary stabilization may be worth considering. 


\section{References}

Blinder, Alan S. (1997), "Is Government Too Political?,” Foreign Affairs 76, No. 6, 115-126.

Blinder, Alan S. (1998), Central Banking in Theory and Practice, MIT Press, Cambridge, Massachusetts.

Bruno, M. and Easterly, W. (1998), "Inflation Crises and Long-Run Growth,” Journal of Monetary Economics 41, February, 3-26.

Corsetti, Giancarlo, Lars Calmfors, Seppo Honkapohja, John Kay, Willi Leibfritz, Gilles Saint-Paul, Hans-Werner Sinn, and Xavier Vives (2003), Report on the European Economy, European Economic Advisory Group at CESifo, Munich.

Cukierman, Alex (1992), Central Bank Strategy, Credibility and Independence: Theory and Evidence, MIT Press, Cambridge, Massachusetts.

Fischer, Stanley (1993), "The Role of Macroeconomic Factors in Growth," Journal of Monetary Economics 32, December, 485-512.

Gylfason, Thorvaldur (1995), The Macroeconomics of European Agriculture, Princeton Studies in International Finance, No. 78, International Finance Section, Princeton University, Princeton, N.J.

Gylfason, Thorvaldur, and Martin Weitzman (2003), "Icelandic Fisheries Management: Fees vs. Quotas,” CEPR Discussion Paper No. 3849, March.

Gylfason, Thorvaldur, and Tryggvi Thor Herbertsson (2001), "Does Inflation Matter for Growth?," Japan and the World Economy 13, December, 405-428.

Khan, Moshin S., and Senhadji, A. S. (2001), "Threshold Effects in the Relationship Between Inflation and Growth," International Monetary Fund Staff Papers 48, No. $1,1-21$.

Lindbeck, Assar, and Mats Persson (2003), "The Gains from Pension Reform," Journal of Economic Literature 41, March, 74-112.

Nelson, Richard R., and Edmund S. Phelps (1966), "Investments in Humans, Technological Diffusion and Economic Growth," American Economic Review 56, May, 69-75.

Sachs, Jeffrey D., and Andrew M. Warner (1995, revised 1997, 1999), "Natural Resource Abundance and Economic Growth,” NBER Working Paper 5398, Cambridge, Massachusetts. 
Sala-i-Martin, Xavier (1991), "Growth, Macroeconomics, and Development:

Discussion," Macroeconomics Annual 1991, 368-378.

Temple, Jonathan (2000), "Inflation and Growth: Stories Short and Tall," Journal of Economic Surveys 14, September, 395-426.

World Bank (1997), "Expanding the Measure of Wealth: Indicators of Environmentally Sustainable Development," Environmentally Sustainable Development Studies and Monographs Series No. 17, World Bank, Washington, D.C. 


\section{CESifo Working Paper Series}

(for full list see www.cesifo.de)

1051 Carlos Fonseca Marinheiro, Output Smoothing in EMU and OECD: Can We Forego Government Contribution? A Risk Sharing Approach, October 2003

1052 Olivier Bargain and Nicolas Moreau, Is the Collective Model of Labor Supply Useful for Tax Policy Analysis? A Simulation Exercise, October 2003

1053 Michael Artis, Is there a European Business Cycle?, October 2003

1054 Martin R. West and Ludger Wößmann, Which School Systems Sort Weaker Students into Smaller Classes? International Evidence, October 2003

1055 Annette Alstadsaeter, Income Tax, Consumption Value of Education, and the Choice of Educational Type, October 2003

1056 Ansgar Belke and Ralph Setzer, Exchange Rate Volatility and Employment Growth: Empirical Evidence from the CEE Economies, October 2003

1057 Carsten Hefeker, Structural Reforms and the Enlargement of Monetary Union, October 2003

1058 Henning Bohn and Charles Stuart, Voting and Nonlinear Taxes in a Stylized Representative Democracy, October 2003

1059 Philippe Choné, David le Blanc and Isabelle Robert-Bobée, Female Labor Supply and Child Care in France, October 2003

1060 V. Anton Muscatelli, Patrizio Tirelli and Carmine Trecroci, Fiscal and Monetary Policy Interactions: Empirical Evidence and Optimal Policy Using a Structural New Keynesian Model, October 2003

1061 Helmuth Cremer and Pierre Pestieau, Wealth Transfer Taxation: A Survey, October 2003

1062 Henning Bohn, Will Social Security and Medicare Remain Viable as the U.S. Population is Aging? An Update, October 2003

1063 James M. Malcomson, Health Service Gatekeepers, October 2003

1064 Jakob von Weizsäcker, The Hayek Pension: An efficient minimum pension to complement the welfare state, October 2003

1065 Joerg Baten, Creating Firms for a New Century: Determinants of Firm Creation around 1900, October 2003 
1066 Christian Keuschnigg, Public Policy and Venture Capital Backed Innovation, October 2003

1067 Thomas von Ungern-Sternberg, State Intervention on the Market for Natural Damage Insurance in Europe, October 2003

1068 Mark V. Pauly, Time, Risk, Precommitment, and Adverse Selection in Competitive Insurance Markets, October 2003

1069 Wolfgang Ochel, Decentralising Wage Bargaining in Germany - A Way to Increase Employment?, November 2003

1070 Jay Pil Choi, Patent Pools and Cross-Licensing in the Shadow of Patent Litigation, November 2003

1071 Martin Peitz and Patrick Waelbroeck, Piracy of Digital Products: A Critical Review of the Economics Literature, November 2003

1072 George Economides, Jim Malley, Apostolis Philippopoulos, and Ulrich Woitek, Electoral Uncertainty, Fiscal Policies \& Growth: Theory and Evidence from Germany, the UK and the US, November 2003

1073 Robert S. Chirinko and Julie Ann Elston, Finance, Control, and Profitability: The Influence of German Banks, November 2003

1074 Wolfgang Eggert and Martin Kolmar, The Taxation of Financial Capital under Asymmetric Information and the Tax-Competition Paradox, November 2003

1075 Amihai Glazer, Vesa Kanniainen, and Panu Poutvaara, Income Taxes, Property Values, and Migration, November 2003

1076 Jonas Agell, Why are Small Firms Different? Managers' Views, November 2003

1077 Rafael Lalive, Social Interactions in Unemployment, November 2003

1078 Jean Pisani-Ferry, The Surprising French Employment Performance: What Lessons?, November 2003

1079 Josef Falkinger, Attention, Economies, November 2003

1080 Andreas Haufler and Michael Pflüger, Market Structure and the Taxation of International Trade, November 2003

1081 Jonas Agell and Helge Bennmarker, Endogenous Wage Rigidity, November 2003

1082 Fwu-Ranq Chang, On the Elasticities of Harvesting Rules, November 2003

1083 Lars P. Feld and Gebhard Kirchgässner, The Role of Direct Democracy in the European Union, November 2003 
1084 Helge Berger, Jakob de Haan and Robert Inklaar, Restructuring the ECB, November 2003

1085 Lorenzo Forni and Raffaela Giordano, Employment in the Public Sector, November 2003

1086 Ann-Sofie Kolm and Birthe Larsen, Wages, Unemployment, and the Underground Economy, November 2003

1087 Lars P. Feld, Gebhard Kirchgässner, and Christoph A. Schaltegger, Decentralized Taxation and the Size of Government: Evidence from Swiss State and Local Governments, November 2003

1088 Arno Riedl and Frans van Winden, Input Versus Output Taxation in an Experimental International Economy, November 2003

1089 Nikolas Müller-Plantenberg, Japan’s Imbalance of Payments, November 2003

1090 Jan K. Brueckner, Transport Subsidies, System Choice, and Urban Sprawl, November 2003

1091 Herwig Immervoll and Cathal O'Donoghue, Employment Transitions in 13 European Countries. Levels, Distributions and Determining Factors of Net Replacement Rates, November 2003

1092 Nabil I. Al-Najjar, Luca Anderlini \& Leonardo Felli, Undescribable Events, November 2003

1093 Jakob de Haan, Helge Berger and David-Jan Jansen, The End of the Stability and Growth Pact?, December 2003

1094 Christian Keuschnigg and Soren Bo Nielsen, Taxes and Venture Capital Support, December 2003

1095 Josse Delfgaauw and Robert Dur, From Public Monopsony to Competitive Market. More Efficiency but Higher Prices, December 2003

1096 Clemens Fuest and Thomas Hemmelgarn, Corporate Tax Policy, Foreign Firm Ownership and Thin Capitalization, December 2003

1097 Laszlo Goerke, Tax Progressivity and Tax Evasion, December 2003

1098 Luis H. B. Braido, Insurance and Incentives in Sharecropping, December 2003

1099 Josse Delfgaauw and Robert Dur, Signaling and Screening of Workers' Motivation, December 2003

1100 Ilko Naaborg,, Bert Scholtens, Jakob de Haan, Hanneke Bol and Ralph de Haas, How Important are Foreign Banks in the Financial Development of European Transition Countries?, December 2003 
1101 Lawrence M. Kahn, Sports League Expansion and Economic Efficiency: Monopoly Can Enhance Consumer Welfare, December 2003

1102 Laszlo Goerke and Wolfgang Eggert, Fiscal Policy, Economic Integration and Unemployment, December 2003

1103 Nzinga Broussard, Ralph Chami and Gregory D. Hess, (Why) Do Self-Employed Parents Have More Children?, December 2003

1104 Christian Schultz, Information, Polarization and Delegation in Democracy, December 2003

1105 Daniel Haile, Abdolkarim Sadrieh and Harrie A. A. Verbon, Self-Serving Dictators and Economic Growth, December 2003

1106 Panu Poutvaara and Tuomas Takalo, Candidate Quality, December 2003

1107 Peter Friedrich, Joanna Gwiazda and Chang Woon Nam, Development of Local Public Finance in Europe, December 2003

1108 Silke Uebelmesser, Harmonisation of Old-Age Security Within the European Union, December 2003

1109 Stephen Nickell, Employment and Taxes, December 2003

1110 Stephan Sauer and Jan-Egbert Sturm, Using Taylor Rules to Understand ECB Monetary Policy, December 2003

1111 Sascha O. Becker and Mathias Hoffmann, Intra-and International Risk-Sharing in the Short Run and the Long Run, December 2003

1112 George W. Evans and Seppo Honkapohja, The E-Correspondence Principle, January 2004

1113 Volker Nitsch, Have a Break, Have a ... National Currency: When Do Monetary Unions Fall Apart?, January 2004

1114 Panu Poutvaara, Educating Europe, January 2004

1115 Torsten Persson, Gerard Roland, and Guido Tabellini, How Do Electoral Rules Shape Party Structures, Government Coalitions, and Economic Policies? January 2004

1116 Florian Baumann, Volker Meier, and Martin Werding, Transferable Ageing Provisions in Individual Health Insurance Contracts, January 2004

1117 Gianmarco I.P. Ottaviano and Giovanni Peri, The Economic Value of Cultural Diversity: Evidence from US Cities, January 2004

1118 Thorvaldur Gylfason, Monetary and Fiscal Management, Finance, and Growth, January 2004 